\title{
Legal Remedy for Climate Change Refugees: Possibilities and Challenges
}

\author{
Yu GONG \\ Law School of Xiamen University, Xiamen, 361005, China \\ gongyu@xmu.edu.cn
}

Keywords: Climate Change; Refugee; Legal Remedy

\begin{abstract}
The purpose of this article is to probe the possible legal remedy under the framework of international for refugees caused by climate change damage. After analyzing the issue from the perspective of international refugee law, international human rights law, and the law of transboundary damage, this article concludes that although the existing legal system may provide some remedy for climate change refugees, it is no well-equipped to solve the whole problem. The best approach to cope with this problem is to devise an innovative legal instrument that is elaborately tailored to climate change refugees.
\end{abstract}

\section{Introduction}

Climate change, which threats our Earth as well as our lives in various ways, is currently one of the most significant and urgent international problems. Among various damages caused by climate change, the loss of inhabitable land and subsequent displacement of residents may be the most serious. As climate change stimulates a rise in sea level, coastal communities and islands are experiencing destructive erosion of land and flooding of habitation. As a result, residents of low-lying communities and small islands will be forced to flee their homes and become "climate change refugees".

Although the present legal framework for addressing climate change established binding commitment with regard to GHG mitigation, there is no mechanism of liability or responsibility, which is indispensable to assuring that those vulnerable states and people who are adversely affected by human-induced climate change could be redressed or remedied. This Article attempts to explore the possible ways that could provide redress and remedy to climate change refugees, as well as the challenges ahead.

\section{Sea Level Rise and Climate Change Refugees}

\section{Global Warming and Sea Level Rise}

Global warming refers to "the rise of average temperature of Earth's atmosphere and its projected continuation". It is confirmed by scientific data that the average surface temperature above the land and ocean has increased by approximately zero point eight degrees Celsius during the past century, and approximately two thirds of this noticeable increase has taken place during the last thirty years [1]. Though some people are still skeptical about this conclusion, the warming of our planet including its ecosystem is indisputable, which is evidenced by various scientific observations, such as the increment of global average temperature in atmosphere, widespread thawing of ice and snow, and rising of global average sea level.

Although the threats as well as impacts of global warming are far-reaching, it is generally believed that sea level rise is one of the most serious consequences. According to IPCC, observations since 1961 show that the average annual rate of global sea level rise is 0.0018 meter over 1961 to 2003, and 0.0031 meter during the period of 1993-2003. Even though all states cut their GHG emissions to nil, the process of sea levels rising will still go on for hundreds of years. The IPCC conservatively projected sea level rise of 0.18 - 0.59 meter within the twenty-first century, estimating that the rate would further increase [2]. 


\section{Emergence of Climate Change Refugees}

Though all coastal regions are being threaten by sea level rise, small islands are regarded to be especially vulnerable. Rising sea level will bring about various coastal disasters such as soil erosion, storm surge, and inundation, and threaten vital facilities, settlements and infrastructure which are indispensable to island inhabitants' lives. When small island states gradually lose inhabitable land because of climate change-induced sea level rise, the residents will be forced to flee their homelands and seek shelter in other countries, and in this sense they will be labeled as "climate change refugees" [3]. It has been estimated that by the middle of the twenty-first century, the number of climate change refugees will reach 200 million [4].

It is widely recognized that the tragedy facing small island states is to a large extent attributed to GHG emissions produced by other states of this world. In fact, small island states that would probably experience the worst of the negative effects of climate change are often those who have contributed the least to the climate change. Therefore, it seems totally unfair letting residents of small island countries shoulder all burden of the whole world's development. Since climate change is a global problem, the whole international society, especially developed countries that play the biggest contributory role in climate change, should bear responsibility for providing remedy to climate change refugees.

\section{Remedy under International Refugee Law}

\section{Existing Refugee Regimes}

Having its origins in the Inter-War years, the contemporary refugee regime was created after World War II and comprises two main elements: (i) the 1951 Convention on the Status of Refugees (the 1951Convention) prescribes who could be regarded as a refugee and lists the rights to which he or her is entitled; (ii) the Office of the United Nations High Commissioner for Refugees (UNHCR) has responsibility for overseeing states' implementation of the Convention.

Article 1 of the 1951Convention, which was amended by the 1967 Protocol, gives the legal definition of refugee: "a person who owing to a well-founded fear of being persecuted for reasons of race, religion, nationality, membership of a particular social group or political opinion, is outside the country of his nationality and is unable or, owing to such fear, is unwilling to avail himself of the protection of that country; or who, not having a nationality and being outside the country of his former habitual residence as a result of such events, is unable or, owing to such fear, is unwilling to return to it."

If a person fit the 1951 Convention definition and thus acquires a refugee status, he or she will be entitled to extensive protections provided by the Convention. Based on the principles of non-discrimination, non-penalization and non-refoulement, refugees should not be sent back to the original country where they have been persecuted, and should also be allowed to resettle as well as start their new lives in receiving states. What is more, such protections should be given to a refugee regardless of whether or not he or she violates the host state's immigration regulations when he or she enters the borderline of the host state [5].

\section{The Legal Gap}

Although the contemporary refugee regime provides wide legal protections for refugees, the precondition of enjoying these protections is very high. The definition of refugee set up by the 1951 Convention requires several key elements: (i) there is a fear of persecution; (ii) such fear is well-founded; and (iii) the persecution is based on "reasons of race, religion, nationality, membership in a particular social group, or political opinion” [6].

However, climate change refugees, a new conception which emerged almost fifty years after the ratification of 1951 Convention, cannot easily match the legal definition set up by the Convention. Since climate change refugees move off their homeland mainly due to the loss of inhabitable land caused by climate change, rather than the well-founded fear of persecution based on "reasons of race, 
religion, nationality, membership in a particular social group, or political opinion”, it will be difficult (if not impossible) for climate change refugees to enjoy protections provided by the 1951 Convention.

Some regional agreements on refugee protection provide expanded and more objective definitions of refugee beyond the 1951 Convention. For example, the Organization of African Unity (OAU) Convention Governing the Specific Aspects of Refugee Problems in Africa (1969) enlarged definition of the 1951 Convention by adding to refugee "any person compelled to leave his/her country owing to external aggression, occupation, foreign domination or events seriously disturbing public order in either part or the whole of his country of origin or nationality." The Cartagena Declaration (1984) adopted by a group of Latin American governments states that "refugee" includes: "persons who flee their countries because their lives, safety or freedom have been threatened by generalized violence, foreign aggression, internal conflicts, massive violation of human rights or other circumstances which have seriously disturbed public order” .

Although environmental disasters may be regarded as "events seriously disturbing public order" or "circumstances which have seriously disturbed public order", the protection provided by the OAU Convention and Cartagena Declaration is quite limited in case when those who seek refugee status merely fit the expanded definitions. Specifically speaking, in the framework of the OAU Convention, those refugee-seekers who fall short of the definitional requirements prescribed by the 1951 Convention are only entitled to temporary protection; and in the framework of the Cartagena Declaration, the protections for such refugee-seekers are even lower in comparison with protections under the OAU Convention, for the simple reason that the expanded definition of refugee which was proposed by the Cartagena Declaration has no official or formal binding force on its signatory parties [7].

\section{Remedy under Human Right Law}

\section{Climate Change and Human Rights}

Climate change has long been regarded as just an environmental problem; but to some extent, it could be regarded as a human rights problem as well. Although the right to a healthy and safe environment has not been identified in multinational human rights treaties such as the two universally-accepted Covenants, human rights institutions of the United Nations have long recognized that environment is intrinsically connected with the enjoyment of many internationally recognized human rights, among them the right to housing, to water, to food, to health, and to life.

In January 2009, the Office of the United Nations High Commissioner for Human Rights (OHCHR) published its report on climate change and human rights, which provides some general observations with regard to some possible connections betwixt human rights and climate change: (1) although climate change may have potential implications for a wide range of human rights, certain specific rights are most directly affected, i.e. "the right to health; the right to water; the right to adequate food; the right to housing; the right to life; and the right to self-determination"; (2) human rights impacts of climate change will be felt unevenly between nations, the most vulnerable would be the states sitting in "front line" of climate change (such as small island states), where global warming can cause catastrophic consequences for human rights; (3) climate change is very likely to lead to large-scale human rights crises, among them the forced displacement across national borderlines, which would take place if small island states are totally submerged by water [8].

\section{Obstacles to Human Rights Remedy}

As far as climate change refugees are concerned, nobody doubts that climate change seriously affected their enjoyment of human rights. It is also obvious that the tragedy small island states face is caused by the irresponsible environmental actions of countries beyond their borders and far beyond their effective control, especially those of developed countries. Then, should developed countries, which contributed the most to climate change and sea level rise, be held accountable to climate 
change refugees under human rights law? The answer seems confirmative. In fact, in as early as 2005, Inuit Circumpolar Conference (ICC) filed a complaint to the Inter-American Commission on Human Rights, accusing the United States -- the world's leading producer of GHG -- of violating human rights of the Inuit through its vast GHG emissions. According to this petition, "the rights to retain one's culture, life, food, and health are fundamental in international law. Global warming violates these rights by melting the ice, snow and permafrost, changing the weather, and radically altering every aspect of the arctic environment on which Inuit lives and culture depend" [9].

However, two main obstacles must be overcome before climate change refugees could obtain remedy under human rights law. First, it must be established that the rest of the world (especially developed countries) owes human rights obligations to climate change refugees; and second, human-induced climate change violated these human rights obligation.

Though it has been generally believed that states should bear legal obligations to respect and ensure the rights of persons subject to or within their jurisdiction, it is often contested and unclear whether these obligations could and should be expended extraterritorially. Article 2(1) of the International Covenant on Civil and Political Rights (ICCPR) requires each of its parties "to respect and to ensure to all individuals within its territory and subject to its jurisdiction the rights recognized in the present Covenant”. Though the Human Rights Committee's comment on this Article said that "a State party must respect and ensure the rights laid down in the Covenant to anyone within the power or effective control of that State Party, even if not situated within the territory of the State Party”, it usually refers to the situation when a state's ICCPR obligation is triggered as a result of that state's exercise of military occupation or control in areas other than its own territory. However, no one could so far authoritatively answer the following question: whether the victims of climate change damage - a special form of transboundary environmental damage - could be regarded as persons who are under effective control of certain or all GHG emitting states [10].

Even if there are extraterritorial human right obligations, it is still not easy to tell whether specific impacts caused by climate change would in a legal sense amount to human rights violations. On the one hand, the causation between a particular state's historical/current GHG emissions and a specific effect of climate change as well as its human rights implications is extremely complicated and therefore is nearly impossible to establish. On the other hand, some climate change-related disasters (like water stress, environmental degradation and hurricanes) are caused by multiple factors and GHG emission is only one of them. In this context, it would be difficult to determine to what degree the human rights impacts of a particular climate change-related disaster could be attributed to GHG emission induced global warming [11].

\section{Remedy under the Regime of Transboundary Damage}

\section{Transboundary Damage and the No-harm Rule}

Climate change refugees are victims of climate change damage. Climate change damage is transboundary in nature, for whatever impairment suffered by any specific state could always be attributed to historical as well as current GHG emissions of all states around the world. Therefore, climate change refugees may also obtain remedy under the regime of state responsibility for transboundary damage.

Transboundary damage could be defined in international law as damage caused by human activities taking place in the territory or under the jurisdiction or control of one state (which could be labeled as the state of origin), to persons, property or the environment in another state or in the common areas beyond national jurisdiction and control [12]. According to International Law Commission's Draft Articles on Responsibility of States for Internationally Wrongful Acts, the state of origin should bear state responsibility for transboundary damage when the conduct - either an action or omission - which is attributable to it constitutes a violation of an international obligation. In another word, state responsibility for transboundary damage premises on the violation of an effective international obligation, i.e. primary rule. 
Concerning transboundary damage, the "no-harm rule", which provides that no state should damage other state's rights, has become a universally recognized rule of customary international law. In the frequently cited case of Trail Smelter, the Tribunal noted that: "under principles of international law, as well as the law of the United States, no state has the right to use or permit the use of territory in such a manner as to cause injury by fumes in or to the territory of another or the properties or persons therein, when the case is of serious consequence and the injury is established by clear and convincing evidence.” The International Court of Justice (ICJ) reinforced this approach in the Corfu Channel case that it was the obligation of every state "not to allow knowingly its territory to be used for acts contrary to the rights of other states". In an Advisory Opinion concerning whether the threat or use of nuclear weapons is lawful, the International Court of Justice further asserted: "the existence of the general obligation of states to ensure that activities within their jurisdiction and control respect the environment of other states or of areas beyond national control is now part of the corpus of international law relating to the environment” [13].

\section{Application of the No-harm Rule}

The "no-harm rule" provides legal basis for state responsibility for transboundary damage, but it does not mean that state of origin should bear responsibility for any transboundary damage. What is decisive is not the existence of transboundary damage per se, but the breach of obligation. The "no-harm rule" does not set up an obligation of result, but an obligation of behavior. In the context of climate change, we could not draw a conclusion according to international law that any given state should bear legal responsibility for relative damage simply because it emits greenhouse gases and thus contributes to global warming. In fact, the application of "no-harm rule" must be based on fault, i.e. it must be established that the conduct of state has violated certain standard of care [14].

It is widely accepted the standard of behavior set up by the "no-harm rule" is "due diligence". In a general sense, the standard of due diligence, as a widely accepted international and objective standard, could be characterized as the behavior that one could expect from a good government. For the purpose of preventing climate change damages, acting with due diligence requires, at the least, that climate policies and respective regulations are in place which aim at reversing the trend of ever increasing GHG emissions. It could be concluded from leading writings and jurisprudence that a standard of care required by "due diligence" consists of three common elements: (i) there must be opportunity for states to take actions to prevent damage; (ii) states should be able to foresee or actually know that certain kind of activities will cause transboundary damage; and (iii) the measures taken by states to prevent damage or minimize risk should be in consistent with the principle of proportionality [15].

To judge whether there is a violation of the "no-harm rule", the most difficult task is judging whether the measures a state taken to minimize the risk or prevent damage is consistent with the principle of proportionality. When making such judgment, we should fairly evaluate all relevant elements such as the physical potential of mitigation, GHG emissions contribution, and the capacity of that state. Therefore, what seems quite understandable is that the degree of care expected from developed countries should be different from many developing countries which are still struggling against poverty. This is also consistent with the principle of "common but differentiated responsibilities”, which is clearly included and emphasized in the UNFCCC [16]. With this in mind, developed countries are more likely to be found to violate the "no-harm rule", because many of them have failed to take appropriate and proportionate measures to prevent climate change harm or minimize risk timely.

\section{Summary}

Sea level rise caused by climate change is a threat to the survival of many low-lying island countries such as Tuvalu, Maldives and Kiribati. Millions of residents in small island states will be forced to flee their homelands and seek livelihoods in new communities crossing state borders. However, the international legal and policy framework seems not prepared for the emerging problem 
of climate change refugees. First, climate change refugees cannot easily match the legal definition set up by the Convention on the Status of Refugees (1951), therefore could not enjoy the extensive legal protections provided by this Convention. Second, it is true that climate change negatively affects the realization of many recognized human rights, but legal remedy under existing human rights regime is faced with insurmountable obstacles due to the unclearness of extraterritorial human rights obligations. Relatively speaking, the remedy under regime of transboundary damage is a more practical way for climate change refugees, if state responsibility could be established. Though the "no-harm rule" provides legal basis for state responsibility for transboundary damage, it does not mean that state of origin should bear liability owing to mere emergence of climate change refugees per se. Since application of the "no-harm rule" must be based on fault, it must be established that the conduct of state has violated certain standard of care - due diligence, which should be characterized as the behavior that one could expect from a good government, and should be judged case by case. In practice, developed countries are more likely to be found to violate the "no-harm rule", because many of them have failed to take appropriate and proportionate measures to prevent climate change harm or minimize risk timely.

From a long-term perspective, the best approach to cope with this situation is to devise an innovative legal instrument that is elaborately tailored to climate change refugees. This instrument should not only ensure that humanitarian aid and human rights protections are fully available to those who are forced to flee their homelands due to the threats of climate change, but also ensure that the cost of supplying such assistance be allocated fairly among all relevant countries and the international society [17]. What is desirable, suggested by some scholars, is to set up an administration mechanism in charge of the implementation of such instrument, which may consist of one coordination body, one international foundation, as well as one group of scientists and specialists [18].

\section{References}

[1] Committee on America's Climate Choices, America's Climate Choices, The National Academies Press, Washington, D.C., 2011, p. 15.

[2] IPCC, Summary for Policymakers, IPCC, Geneva, 2007, p.3.

[3] B. Docherty and T. Giannini, Confronting a rising tide: a proposal for a convention on climate change refugees, Harv. Envtl. L. Rev. 33 (2009) 361.

[4] O. Brown, Climate Change and Forced Migration: Observations, Projections and Implications, UNDP, Geneva, 2007, p. 5.

[5] J. B. Cooper, Environmental refugees: meeting the requirements of the refugee definition, N.Y.U. Envtl. L.J. 6 (1998) 481.

[6] T. V. Duong, When Islands Drown: The plight of "climate change refugees" and recourse to international human rights law, U. Pa. J. Int'l L. 31 (2010) 1249.

[7] C. O. Miranda, Toward a broader definition of refugee: 20th century development trends, Calif. West Int'l L. J. 20 (1990) 323-324.

[8] OHCHR, Report on the Relationship between Climate Change and Human Rights, OHCHR, Geneva, 2009, pp. 8-21.

[9] Inuit Circumpolar Conference, Petition to the Inter American Commission on Human Rights, December 7 , 2005, on http://earthjustice.org/library/legal_docs/petition-to-the-inter-american-commission-on-human-right s-on-behalf-of-the-inuit-circumpolar-conference.pdf.

[10] J. H. Knox, Climate change and human rights law, Va. J. Int'l L. 50 (2009) 202-203. 
[11]OHCHR, Report on the Relationship between Climate Change and Human Rights, OHCHR, Geneva, 2009, p. 23.

[12]X. Hanqin, Transboundary Damage in International Law, Cambridge University Press, New York, 2003, p.10.

[13] M. N. Shaw, International Law, 6th ed., Cambridge University Press, Cambridge, 2008, pp.851-853.

[14] R. Verheyen and P. Roderick, Beyond Adaptation: The Legal Duty to Pay Compensation for Climate Change Damage, WWF-UK, Woking, 2008, p.16.

[15] R. Verheyen, Climate Change Damage and International Law, Martinus Nijhoff Publishers, Leiden, 2005, p.176.

[16] C. Voigt, State responsibility for climate change damages, Nord. J. Int'l L. 77 (2008) 12-13.

[17] \& [18] B. Docherty and T. Giannini, Confronting a rising tide: a proposal for a convention on climate change refugees, Harv. Envtl. L. Rev. 33 (2009) 402. 